\title{
Large hydropower and water-storage potential in future glacier-free basins
}

\author{
Daniel Farinotti ${ }^{1,2 *}$, Vanessa Round ${ }^{1,2}$, Matthias Huss $^{1,2,3}$, Loris Compagno $0^{1,2}$ \& Harry Zekollari ${ }^{1,2}$
}

\begin{abstract}
Climate change is causing widespread glacier retreat ${ }^{1}$, and much attention is devoted to negative impacts such as diminishing water resources ${ }^{2}$, shifts in runoff seasonality ${ }^{3}$, and increases in cryosphere-related hazards ${ }^{4}$. Here we focus on a different aspect, and explore the water-storage and hydropower potential of areas that are expected to become ice-free during the course of this century. For roughly 185,000 sites that are glacierized at present, we predict the potentially emerging reservoir storage volume and hydropower potential. Using a climate-driven glacier-evolution model $^{5}$ and topographical analysis ${ }^{6}$, we estimate a theoretical maximal total storage and hydropower potential of $875 \pm 260$ cubic kilometres and $1,355 \pm 515$ terawatt-hours per year, respectively ( $95 \%$ confidence intervals). A first-order suitability assessment that takes into account environmental, technical and economic factors identifies roughly 40 per cent of this potential $(355 \pm 105$ cubic kilometres and $533 \pm 200$ terawatt-hours per year) as possibly being suitable for realization. Three quarters of the potential storage volume is expected to become ice-free by 2050 , and the storage volume would be enough to retain about half of the annual runoff leaving the investigated sites. Although local impacts would need to be assessed on a case-by-case basis, the results indicate that deglacierizing basins could make important contributions to national energy supplies in several countries, particularly in High Mountain Asia.
\end{abstract}

Widespread glacier retreat is causing huge changes to glacierized landscapes around the globe ${ }^{1}$. Further changes are already inevitable, with glaciers expected to lose a substantial fraction of their volume even if ongoing climatic warming were to stall ${ }^{7}$. Under scenarios of high greenhouse-gas emission, glaciers are predicted to disappear almost completely in many regions ${ }^{8}$. Although negative impacts such as changing water availability ${ }^{2,3}$, cryosphere-related hazards ${ }^{4}$ and sea-level rise $^{9}$ are well recognized, newly emerging ice-free basins have sometimes been suggested to provide opportunities as well ${ }^{10-12}$. Increasing interseasonal water storage in newly deglacierized areas, for example, has been suggested as a possible mitigation measure against future seasonal water scarcity ${ }^{6}$-an issue threatening the water security of millions of people who live downstream of mountain ranges hosting glaciers ${ }^{2,13,14}$. Similarly, projects to increase energy production and storage through hydropower installations in areas becoming ice-free have been proposed ${ }^{15}$, the flexibility and storage capacity of such schemes being recognized as valuable assets within the increasingly transient energy $\mathrm{mix}^{16}$. Although the idea of constructing dams at former glacier locations might seem implausible at first, the lack of established human land use, the relatively simple ecosystem structures ${ }^{17}$ and the possibility of natural lake emergence ${ }^{11}$ may help to alleviate some of the environmental and social concerns typically associated with hydropower development ${ }^{18,19}$.

Here we quantify the potential storage volume and hydropower production of glacierized areas that are projected to become ice-free within this century. By determining the technical potential and the suitability of developing diversional hydropower plants at each individual glacier in the globally complete Randolph Glacier Inventory ${ }^{20}$ (RGI, version 6), we complement existing studies on the global hydropower potential of non-glacierized surfaces ${ }^{21}$. We virtually place a dam wall at the lowest point of each glacier that is larger than $0.05 \mathrm{~km}^{2}$ and outside of the Sub-Antarctic (see Methods), and use digital elevation models of the subglacial terrain ${ }^{22}$ to simulate the reservoir storage volume of each of the roughly 185,000 sites selected in this way (see Extended Data Fig. 1 for a visualization). The lake volume per dam-wall area is optimized by varying dam orientation, length and height, the latter two parameters being constrained to remain within the range of already-existing, highalpine hydropower infrastructure. The selection criteria are meant to minimize the impact on the landscape (rather than maximizing economic revenue, for example) while maximizing the reservoir volume and thus the flexibility in reservoir operations for both hydropower production and water management. The extent and timing of areas becoming ice-free are provided by the Global Glacier Evolution Model $\left(\right.$ GloGEM) ${ }^{5}$, which is driven by 14 global climate models based on three representative concentration pathways $(\mathrm{RCPs})^{23}$. Annual potential hydropower production during the period $2017-2100$ is estimated using projected basin-runoff from GloGEM and the available hydraulic head-the latter being determined as the maximum elevation drop from the virtual dam location to the surrounding topography (see Methods).

Drawing on principles outlined by the Hydropower Sustainability Assessment Protocol ${ }^{24}$, we also provide an initial assessment of the suitability of every site. We consider a series of independently rated 


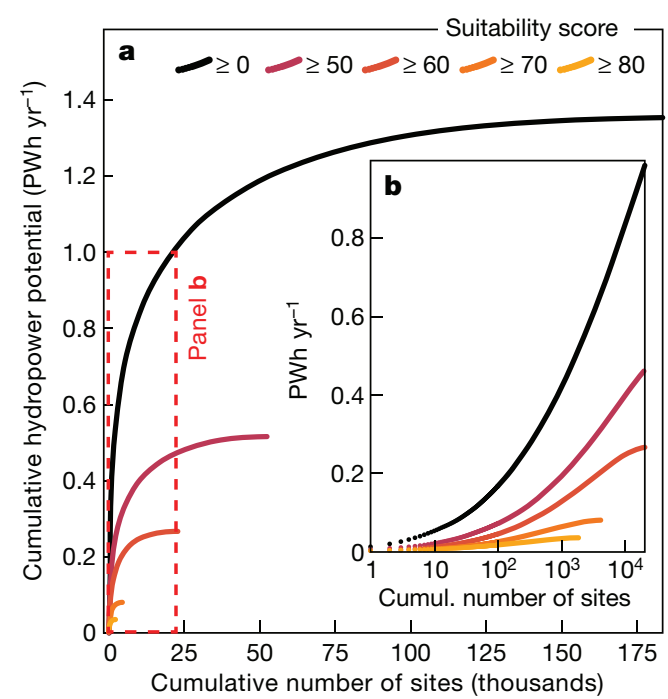

Fig. 1|Global hydropower and water-storage potential from deglacierizing areas. a, Cumulative hydropower potential for a given number of sites $\left(1 \mathrm{PWh}=10^{3} \mathrm{TWh}\right)$. Differently coloured lines depict different suitability-score thresholds. b, Enlargement of the indicated frame (note the logarithmic $x$-axis) c, Temporal evolution of the maximal cumulative hydropower potential (top) and reservoir storage volume (bottom). Results are shown for three

indicators (see Methods) that we group into three categories, reflecting environmental (three indicators), technical (five indicators) and economic (one combined indicator) suitability. Each category is conservatively rated using the value of the worst-scoring indicator in that category, and the final score is obtained by arithmetically averaging these values. The result is a continuous suitability score ranging from 0 (unsuited) to 100 (highly suited). Two environmental and two technical indicators are treated as 'killer' criteria, meaning that an overall score of zero is assigned irrespective of any other indicator if a certain condition is met (see Methods).

In a world in which glaciers have disappeared, we estimate the total, maximal theoretical storage volume of newly deglacierized areas as $875 \pm 260$ cubic kilometres $\left(\mathrm{km}^{3}\right)$ (Fig. $1 \mathrm{c}$, bottom). To put this in perspective, this volume is about $10 \%$ of the worldwide volume of existing artificial lakes ${ }^{25}$, or $48 \%$ of the annual runoff from all glaciers. Using the most conservative scenario of glacier retreat (RCP 2.6), $68 \%$ of the potential reservoir storage volume would be glacier-free by 2050 . This figure changes to around $80 \%$ for RCP 8.5 (a high-emission scenario implying faster glacier retreat).

We estimate the maximal, theoretically achievable hydropower potential from all basins as $1,355 \pm 515$ terawatt-hours per year $\left(\mathrm{TWh} \mathrm{yr}^{-1}\right)$ (average over 2020-2100 and for all scenarios; Fig. 1a). This is equivalent to $7 \%$ of the global total electricity consumption as of 2015 , or $35 \%$ of the global hydropower production ${ }^{26}$. There is little temporal variation in the global hydropower potential, although higher RCPs show higher potential over time owing to increased availability of glacier meltwater (Fig. 1c, top). Note that the global average masks some substantial regional differences in future hydropower potential due to runoff evolution: the general trend towards decreasing annual runoff projected for most regions is compensated by runoff increases in the Arctic regions, particularly under stronger warming scenarios (Extended Data Fig. 2).

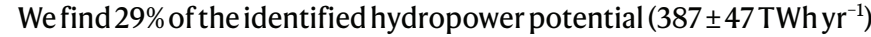
and $24 \%$ of the potential storage volume $\left(212 \pm 63 \mathrm{~km}^{3}\right)$ at sites with suitability scores below 10 (Extended Data Fig. 3). Such a low score is generally due to high levels of environmental protection, technical restrictions including the presence of surging glaciers, lack of reservoir storage or hydraulic head, or high production costs (Extended Data
Fig. 4). The unique nature of glacierized environments, for example, has qualified many sites for UNESCO World Heritage or World Protected Area status ${ }^{27}$ (see Methods for definitions). This results in a suitability score of zero for many sites in New Zealand ( $80 \%$ of the identified potential; Extended Data Fig. 5), Tajikistan (46\%) and the United States (39\%). For $29 \%$ of all investigated sites, on the other hand, the local topography does not yield any potential storage volume because the basins are either too wide, too flat, or too steep. These sites all score low in suitability and add up to $20 \%$ of the maximal hydropower potential when accounted for as run-on-river plants. Finally, high production costs are typically caused by the necessity of connecting remote locations to the existing power grid, or by a low ratio between potential power generation and dam-construction costs (Fig. 1a and Extended Data Fig. 6).

Production costs of less than 0.5 and 0.1 US dollars per kilowatt-hour $\left(\mathrm{USD} \mathrm{kWh}^{-1}\right)$ are estimated to be possible for $60 \%\left(818 \pm 310 \mathrm{TWh} \mathrm{yr}^{-1}\right)$ and $13 \%\left(169 \pm 64 \mathrm{TWh} \mathrm{yr}^{-1}\right)$ of the maximal theoretical hydropower potential, respectively (Fig. $1 \mathrm{~d}$ ). The largest potentials at production costs below 0.1 USD kWh ${ }^{-1}$ are found in High Mountain Asia $\left(101 \pm 38\right.$ TWh yr $^{-1}$ for Central and South Asia; see Extended Data Fig. 7 for definition of regions), Alaska $\left(80 \pm 30 \mathrm{TWh} \mathrm{yr}^{-1}\right)$, Arctic Canada $\left(20 \pm 8 \mathrm{TWh} \mathrm{yr}^{-1}\right)$ and the Southern Andes $\left(18 \pm 7 \mathrm{TWh} \mathrm{yr}^{-1}\right)$. The potential for production costs below $0.5 \mathrm{USD} \mathrm{kWh}^{-1}$ is 1.3 to 8.2 times larger, depending on the region considered (Extended Data Fig. 6).

A suitability score higher than 50 (an inflection point in the cumulative distribution of the scores; Extended Data Fig. 3a) is achieved by $39 \%\left(534 \pm 202 \mathrm{TWh} \mathrm{yr}^{-1}\right)$ of the theoretical hydropower potential (Fig. 1a, b; see Extended Data Fig. 3a for any other score threshold). The amount can be put into perspective by aggregating it per country and comparing it with the national energy consumption ${ }^{28}$ (Fig. 2). The glacier basins of Nepal, Afghanistan, Bhutan and Kyrgyzstan contain enough hydropower potential to exceed present electricity consumption, although this is partly due to very low demand per capita. Other countries with large potential include Tajikistan (82\% of current consumption), Chile (40\%), Pakistan (35\%) and Georgia (31\%). Canada, Iceland, Bolivia, Norway and Switzerland have the potential for 10-23\% of their present consumption, and the numbers become even more important when compared with today's national renewable electricity production (Extended Data Fig. 7). Suitability scores higher than 


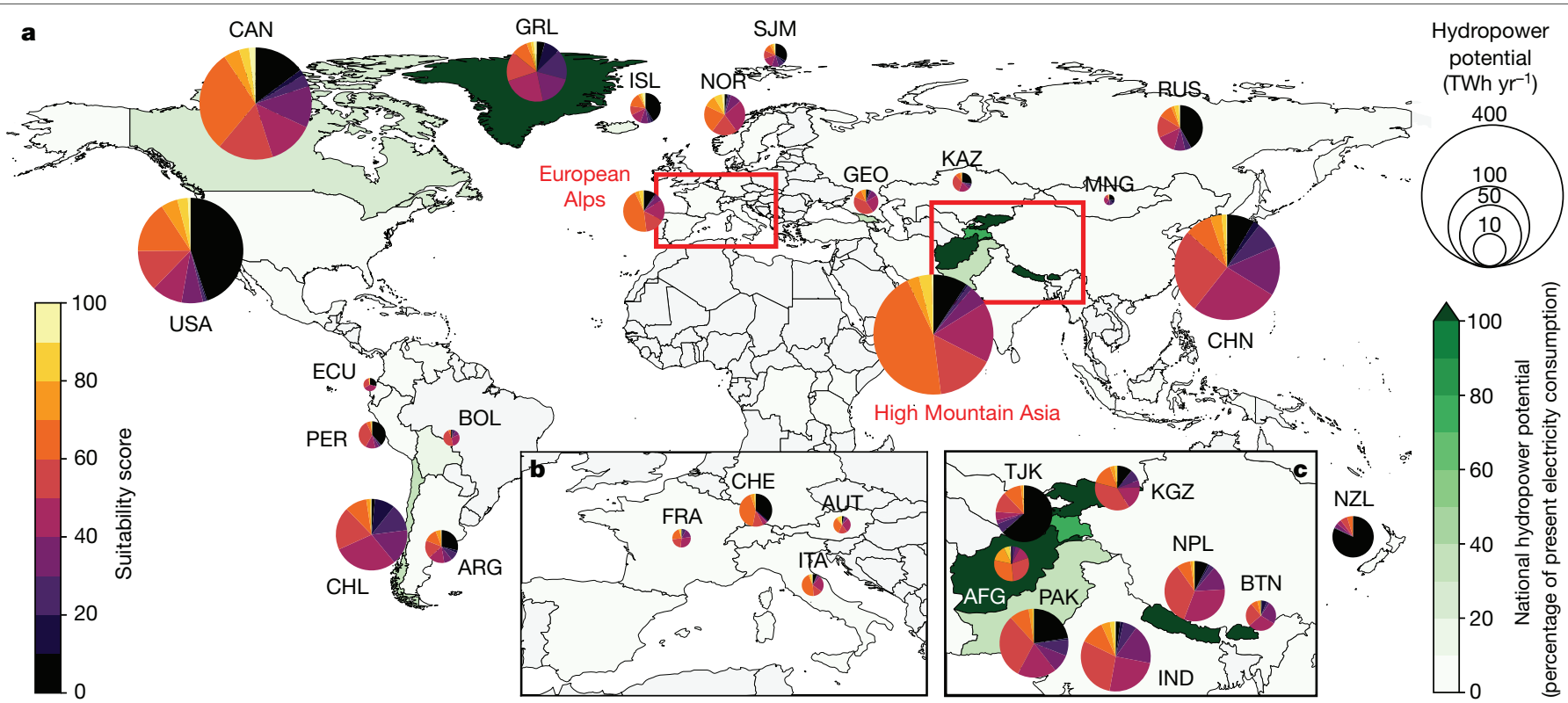

Fig. 2 | Global distribution of the hydropower potential from deglacierizing areas, showing suitability and national significance. $\mathbf{a}-\mathbf{c}$, Countries are coloured according to the nationally aggregated hydropower potential from sites with suitability scores of 50 or more, as a percentage of the present-day national electricity consumption ${ }^{28}$ (green shading). The pie charts show the

75 are found for $4 \%\left(51 \pm 19 \mathrm{TWh} \mathrm{yr}^{-1}\right)$ of the theoretical potential, the highest potentials being located in Canada $\left(15.6 \pm 5.9 \mathrm{TWh} \mathrm{yr}^{-1}\right)$, the US $\left(10.7 \pm 4.1 \mathrm{TWh} \mathrm{yr}^{-1}\right)$, China $\left(6.1 \pm 2.3 \mathrm{TWh} \mathrm{yr}^{-1}\right)$, India $\left(4.1 \pm 1.6 \mathrm{TWh} \mathrm{yr}^{-1}\right)$ and Norway $\left(3.0 \pm 1.1 \mathrm{TWh} \mathrm{yr}^{-1}\right)$.

We emphasize that building a dam at every glacier location is neither realistic, nor sustainable, nor desirable. We find, however, that most of the identified potential comes from a relatively small number of sites. For instance, 1,000 of the roughly 185,000 assessed sites contain $31 \%$ $\left(423 \pm 160 \mathrm{TWhyr}^{-1}\right)$ of the total energy potential (Fig. 1b). The global distribution of the sites with the highest energy potential and the relevant suitability scores are given in Extended Data Fig. 8. The ten largest sites with suitability scores larger than 50 could produce $7 \mathrm{TWh}^{-1} \mathrm{r}^{-1}$ or more in each of USA, China, Canada and Nepal. That is substantial for Nepal (where this energy potential represents 1.9 times the present electricity consumption), but not in China, for example, where this potential pales in comparison with national demand (roughly 5,300 TWh $\mathrm{yr}^{-1}$ ) and the scale of already-planned hydropower developments ${ }^{18}$. In Bhutan, Afghanistan, Kyrgyzstan, Tajikistan and Greenland, fewer than 10 dams would have the potential to provide more than $10 \%$ of national electricity demand (Fig. 3). We note that our estimates consider only the runoff generated within each of the glacierized basins. Although it can be difficult to realize water diversions because of both technical and political constraints, the hydropower potential and the cost efficiency could be substantially increased by diverting water from surrounding basins.

In addition to providing hydropower energy, artificial reservoirs have been suggested to play a role in mitigating changes in seasonal water availability and related water stress ${ }^{6}$. As glaciers shrink, so does their ability to store snow and ice over long time periods, and to release the corresponding water during the melt season ${ }^{3}$. Reservoirs might imitate this storage function, to the benefit of arid regions relying on meltwater during the dry season. The globally aggregated reservoir volume corresponds to $48 \%$ of the average annual runoff from the contributing glacier catchments, hinting at the substantial potential for water management in such sites.

Our analyses are a first quantification of the global potential for hydropower production and water storage in deglacierizing areas. maximal hydropower potential (pie size) broken down by suitability score (pie colours). Countries that are aggregated as European Alps and High Mountain Asia in panel $\mathbf{a}$ are magnified in panels $\mathbf{b}$ and $\mathbf{c}$, respectively. Colour graduations are discretized for better readability. The basemap was generated using Matplotlib 30

Further assessment of the actual feasibility of the locations identified here would be needed on a case-by-case basis. Particularly important will be an understanding of the local energy and development

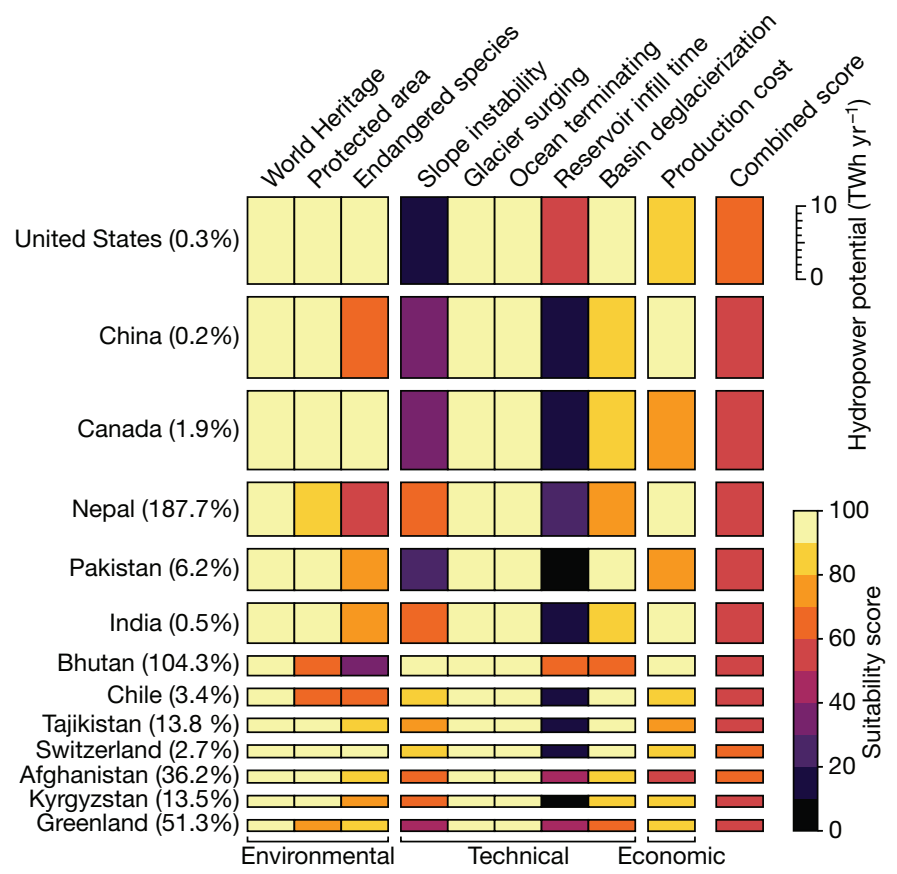

Fig. 3 | Cumulative hydropower potential and average suitability score for the top ten sites per country in terms of total energy potential. Only sites with a suitability score of 50 or more are considered. For each indicated country, the total potential of the largest ten sites is shown by the bar heights. The potentially provided percentage of the national electricity consumption is in parentheses. Colours show the average suitability, grouped into three categories of indicators (labelled at the bottom) and a combined suitability score (see Methods). Only nations with a total potential of more than $1.5{\mathrm{TWh} \mathrm{yr}^{-1}}^{-1}$ are shown. Colour graduations are discretized for better readability. 
framework, a demonstrated need for additional infrastructure, and a detailed environmental, technical and economic feasibility assessment. Changing glacial environments are an emotive topic exemplifying global change in a very tangible way, and outside interference can be met with apprehension ${ }^{12,29}$. Accounting for the concerns and needs of local communities and safeguarding the functioning of downstream ecosystems should be of utmost importance when planning for new infrastructure.

\section{Online content}

Any methods, additional references, Nature Research reporting summaries, source data, extended data, supplementary information, acknowledgements, peer review information; details of author contributions and competing interests; and statements of data and code availability are available at https://doi.org/10.1038/s41586-019-1740-z.

1. Vaughan, D. et al. in Climate Change 2013: The Physical Science Basis. Contribution of Working Group I to the Fifth Assessment Report of the Intergovernmental Panel on Climate Change (eds Stocker, T. et al.) 317-382 (Cambridge Univ. Press, 2013).

2. Immerzeel, W. W, van Beek, L. P. H. \& Bierkens, M. F. P. Climate change will affect the Asian water towers. Science 328, 1382-1385 (2010).

3. Huss, M. \& Hock, R. Global-scale hydrological response to future glacier mass loss. Nat. Clim. Chang. 8, 135-140 (2018)

4. Stoffel, M. \& Huggel, C. Effects of climate change on mass movements in mountain environments. Prog. Phys. Geogr. Earth Env. 36, 421-439 (2012).

5. Huss, M. \& Hock, R. A new model for global glacier change and sea-level rise. Front. Earth Sci. 3, 54 (2015)

6. Farinotti, D., Pistocchi, A. \& Huss, M. From dwindling ice to headwater lakes: could dams replace glaciers in the European Alps? Environ. Res. Lett. 11, 054022 (2016).

Marzeion, B., Kaser, G. Maussion, F. \& Champollion, N. Limited influence of climate change mitigation on short-term glacier mass loss. Nat. Clim. Chang. 8, 305-308 (2018). . Hock, R. et al. GlacierMIP-a model intercomparison of global-scale glacier massbalance models and projections. J. Glaciol. 65, 453-467 (2019).

Church, J. et al. in Climate Change 2013: The Physical Science Basis. Contribution of Working Group I to the Fifth Assessment Report of the Intergovernmental Panel on Climate Change (eds Stocker, T. et al.) 1137-1216 (Cambridge Univ. Press, 2013).

10. Terrier, S., Bieri, M., Jordan, F. \& Schleiss, A. J. Impact du retrait glaciaire et adaptation du potentiel hydroelectrique dans les Alpes suisses. La Houille Blanche 1, 93-101 (2015).
11. Haeberli, W. et al. New lakes in deglaciating high-mountain regions-opportunities and risks. Clim. Change 139, 201-214 (2016).

12. Colonia, D. et al. Compiling an inventory of glacier-bed overdeepenings and potential new lakes in de-glaciating areas of the Peruvian Andes: approach, first results, and perspectives for adaptation to climate change. Water 9, 336 (2017).

13. Best, J. Anthropogenic stresses on the world's big rivers. Nat. Geosci. 12, 7-21 (2019).

14. Pritchard, H. D. Asia's shrinking glaciers protect large populations from drought stress. Nature 569, 649-654 (2019).

15. Kraftwerke Obserhasli AG. Speichersee und Kraftwerk Trift. https://www.grimselstrom.ch/ ausbauvorhaben/zukunft/kraftwerk-trift/ (accessed June 2019).

16. International Renewable Energy Agency. Installed renewable energy capacity. http:// resourceirena.irena.org/gateway/dashboard/?topic=4\&subTopic=16 (2018).

17. Nemergut, D. et al. Microbial community succession in an unvegetated, recently deglaciated soil. Microb. Ecol. 53, 110-122 (2007)

18. Zarfl, C., Lumsdon, A., Berlekamp, J., Tydecks, L. \& Tockner, K. A global boom in hydropower dam construction. Aquat. Sci. 77, 161-170 (2015)

19. Latrubesse, E. et al. Damming the rivers of the Amazon basin. Nature 546, 363-369 (2017).

20. RGI Consortium. Randolph Glacier Inventory-a dataset of global glacier outlines, version 6.0. Technical Report (Global Land Ice Measurements from Space (GLIMS), 2017).

21. Gernaat, D. E. H. J., Bogaart, P. W., van Vuuren, D. P., Biemans, H. \& Niessink, R. Highresolution assessment of global technical and economic hydropower potential. Nat. Energy 2, 821-828 (2017).

22. Huss, M. \& Farinotti, D. Distributed ice thickness and volume of all glaciers around the globe. J. Geophys. Res. 117, F04010 (2012).

23. van Vuuren, D. P. et al. The representative concentration pathways: an overview. Clim. Change 109, 5-31 (2011).

24. International Hydropower Association. Hydropower Sustainability Assessment Protocol Technical Report (International Hydropower Association, 2012).

25. Chao, B., Wu, Y. H. \& Li, Y. S. Impact of artificial reservoir water impoundment on global sea level. Science 320, 212-214 (2008).

26. International Energy Agency (IEA). Key world energy statistics report 2017. https://www. iea.org/publications/freepublications/publication/KeyWorld2017.pdf (2017).

27. Bosson, J.-B., Huss, M. \& Osipova, E. Disappearing World Heritage glaciers as a keystone of nature conservation in a changing climate. Earth's Future 7, 469-479 (2019).

28. The World Bank World development indicators 2018. https://datacatalog.worldbank.org/ dataset/world-development-indicators (2018).

29. Byg, A. \& Salick, J. Local perspectives on a global phenomenon-climate change in Eastern Tibetan villages. Glob. Environ. Change 19, 156-166 (2009).

30. Hunter, J. D. Matplotlib: a 2D graphics environment. Comput. Sci. Eng. 9, 90-95 (2007). 


\section{Methods}

We apply the methods and suitability assessments described below to each individual glacier in the globally complete Randolph Glacier Inventor $\mathrm{y}^{20}$ (RGI, version 6), excluding the Sub-Antarctic and glaciers smaller than $0.05 \mathrm{~km}^{2}$. Each of the 187,268 glaciers is considered to be a separate potential site. The lowest point of the glacierized area-the terminus-is set as the potential dam-wall location and watershedcollection point, limiting our study to areas that are ice-covered at present (years $2002 \pm 10$, as given by the glacier inventory).

\section{Potential storage capacity}

Digital elevation models (DEMs) of the subglacial topography of each location are determined by subtracting the estimated ice thickness (derived from the global ice-thickness model of ref. ${ }^{22}$ ) from DEMs of the glacier surface $^{31,32}$. Dam walls are simulated at the lowest point of each glacier to determine the potential reservoir volume in the future ice-free area. The walls are simulated to be perpendicular to the glacier centre lines ${ }^{33}$, and at rotations of $\pm 15^{\circ}$ and $\pm 30^{\circ}$. The orientation returning the largest ratio of reservoir volume to dam-wall area is selected. Dams are grown to the maximumvolume that can be accommodated by the local ice-free topography, with wall dimensions limited to $800 \mathrm{~m}$ in width and $280 \mathrm{~m}$ in height to reflect the maximum dimensions of existing dams in high-mountain areas. For each site, we calculate the uncertainty in simulated storage volume through the uncertainty in ice thickness from which subglacial topography is inferred. The latter has been assessed to be of the order of $20 \%$ at the point scale and $30 \%$ for the glacier-wide scale ${ }^{34}$. Note that this uncertainty does not affect the estimated hydropower potential, as the storage volume does not enter those computations (see below). By comparison with a manual or a more sophisticated dam-wall placement that further optimizes the location within the valley topography, our simulation provides a conservative estimate for reservoir volumes.

\section{Hydropower potential}

The potential hydropower production over a certain time period, $E_{\mathrm{t}}$ (in watt-hours, Wh), is primarily a function of water availability, available hydraulic head and system design:

$$
E_{t}=\sum_{t} \min \left(Q_{\mathrm{t}}, Q_{\mathrm{D}}\right) \Delta \operatorname{th} \rho g \eta
$$

where $Q_{\mathrm{t}}$ and $Q_{\mathrm{D}}$ are the discharge rate and the design discharge rate (in $\mathrm{m}^{3} \mathrm{~s}^{-1}$ ), respectively; $\Delta t$ is the time step (in hours); $h$ is the available hydraulic head (in m); $\rho g$ is the specific weight of water $\left(9,800 \mathrm{~N} \mathrm{~m}^{-3}\right)$; and $\eta$ is the system efficiency (dimensionless, conservatively estimated as $80 \%$; ref. ${ }^{21}$ ). $Q_{\mathrm{t}}$ is modelled at a monthly resolution (see below), while $Q_{\mathrm{D}}$ is defined as the minimum discharge that is required to turbine the entire basin runoff every year. For sites with no reservoir, $Q_{D}$ is the maximal monthly discharge. For sites with a reservoir, $Q_{D}$ is instead the maximum between the average monthly discharge and the discharge level that, if exceeded, results in a water volume that is equal to the volume of the reservoir (Extended Data Fig. 9). When considering annual electricity production, this definition of $Q_{D}$ allows us to replace $\min \left(Q_{\mathrm{t}}\right.$, $Q_{\mathrm{D}}$ ) in equation (1) with the average annual discharge.

The catchment from which runoff is generated is defined by applying a watershed delineation algorithm ${ }^{35}$ to the DEM of the subglacial topography and the surrounding non-glacierized catchment area. Projections of specific runoff rates at monthly resolution come from the Global Glacier Evolution Model (GloGEM) ${ }^{5}$.GloGEM is a state-of-the-art glacier evolution model that computes glacier mass balance and glacier geometry changes for each individual glacier. The glacierized portion of each catchment has an annually updated geometry (area and elevation distribution), and basin runoff consists of rain and melt (from snow, firn and ice), minus refreezing. Processes such as groundwater recharge or evapotranspiration are not explicitly accounted for, because there is a lack of data to constrain the processes at the considered scale, and because their contribution is expected to be small in the addressed, highly glacierized catchments. GloGEM is driven by climate projections from 14 global climate models $(\mathrm{GCMs})^{36}$, which in turn account for three future greenhouse gas concentration pathways ${ }^{23}:$ RCP 2.6, 4.5 and 8.5. Annual average discharge rates are computed by averaging over the $14 \mathrm{GCMs}$ and all months of the year. The presented values for hydropower potential are averages over the years 2020-2100 and all three emission scenarios.

The available hydraulic head over which hydropower could be produced is determined for each site as the maximum topographic drop from the base of the simulated dam wall to a maximum distance of 2,4 , $6,8,10,12$ and $15 \mathrm{~km}$. Topographic drops are determined using the 3 -arcsecond Viewfinder Panoramas global DEM ${ }^{37,38}$. The range of distances over which the hydraulic head is calculated provides possible energyproduction options for each site. For each option we estimate a production cost (see 'Economic indicators' below), and we choose the option with the lowest cost per unit of produced energy. We use the standard deviation of the hydraulic heads calculated with the various options ( $16 \%$ on average) as an estimate of the corresponding uncertainty.

The uncertainty in total energy potential, averaged over all climate models, all emissions scenarios, and all years from 2020-2100, is estimated as $\pm 33 \%$. The individual uncertainty components, combined in quadrature, stem from the estimated hydraulic head $( \pm 16 \%)$, the 14 different climate models $( \pm 20 \%)$, the three emissions scenarios $( \pm 12 \%)$, and temporal variation over the considered period $( \pm 17 \%)$. We assume that all runoff is available for energy production but neglect the possibility of diverting water from beyond the watershed. Note that calculations of potential hydropower production are independent of the potential dam volume assessments (the dam volume does not feature in equation (1)). Sites with a topography that is unfavourable for dam construction can therefore be thought of as run-on-river power plants. Such a lack of storage capacity, however, is penalized in the suitability score.

\section{Suitability score}

We rate the suitability of each potential site with a score ranging from 0 (unsuited) to 100 (highly suited). The score is the average value assigned to three equally weighted categories that account for environmental, technical and economic factors. The individual categories comprise between one and five independently rated indicators (again with a value between 0 and 100 ), and the value of the worst-scoring indicator is conservatively assigned to the corresponding category. Some indicators are treated as 'killer' criteria, meaning that if a given criterion is met, an overall suitability score of 0 is assigned irrespective of any other indicator. Details for the computation of individual indicator are given below.

Environmental indicators. Environmental indicators include: (1) the presence of UNESCO World Heritage Sites (retrieved from ref. ${ }^{39}$ ); (2) the presence of otherwise protected areas (taken from the World Database on Protected Areas (WDPA ${ }^{40}$ ); and (3) the density of endangered species (obtained from the Global Amphibian and Mammal Species Richness Grids of the International Union for Conservation of Nature ${ }^{41,42}$ ).

Species-richness grids are available with 30 -arc-second resolution, and vector data for UNESCO and protected areas are gridded to the same resolution. Information for every potential site is obtained by intersecting the so-obtained grids with the position of the glacier terminus. The scores for the three indicators are assigned as follows: 0 (100) if a location is (is not) within an UNESCO area; 0 (50) if a location is rated as category I (category II) in the WDPA; and 100 if it is rated as category III or is not classified; ' $100-10 N$ ' for the density of endangered species, $N$ being the number of such species (score $=0$ for $N \geq 10$ ). UNESCO and WDPA category I status are treated as killer criteria.

Technical indicators. Technical indicators include:(1) the reservoir infill time; (2) the risk of slope instabilities; (3) the timing by which a given reservoir is projected to become ice-free; (4) the risk of rapid glacier advance (surging); and (5) the presence of an ocean-terminating glacier. 
Reservoir infill time-calculated as the ratio between the potential dam volume and the projected annual inflow-is a widely used metric in hydropower engineering. Dams with large infill times are favourable because they have larger potential for storage and water-management purposes, and longer lifespan in terms of sediment infill. A score of 100 is assigned for infill times of more than 6 months, and the score decreases linearly to 0 for zero infill time. The latter also occurs when the reservoir volume is zero-that is, when no suitable dam can be simulated within the imposed dimension limits (a common occurrence when the subglacial topography is very wide, very flat or very steep).

We roughly assess the risk of slope instabilities from the 80th percentile of a basin's slope (a metric identifying very steep parts of the basin). The likelihood of high-alpine slope instabilities increases substantially when the slope is steeper than $40^{\circ}\left(\right.$ ref. $\left.^{43}\right)$. A linear score is assigned in the slope range $40 \pm 10^{\circ}$, with scores of 0 and 100 assigned to basins with slopes above $50^{\circ}$ and below $30^{\circ}$, respectively. Earthquake risk is accounted for in the calculations of production costs (see below).

The timing by which a given reservoir becomes ice-free-which is central to the concept of using currently glacierized areas as potential reservoir locations-is assessed through the GloGEM results (see above). More specifically, the timing is determined as the year by which the lowest glacier elevation rises above the elevation of the simulated dam crest. The most conservative estimate from the three climate scenarios (latest retreat) is used. A score of 0 (or 100) is assigned if the reservoir remains ice-covered until 2100 (or 2040), with a linear score in between.

Surging and ocean-terminating glaciers impose risks on the potential infrastructure from rapid glacier advance and ocean waves, respectively. Surging glaciers are identified through a recent inventor ${ }^{44}$, while ocean-terminating glaciers are determined from the elevation of their terminus. Both indicators are binary (with a score of either 0 or 100) and are treated as killer criteria. Note, moreover, that ocean-terminating sites bear only minimal hydropower potential, as their hydraulic head is limited to a fraction of the potential dam height.

Economic indicators. Economic indicators consider only the cost of hydropower production. The calculations are based on the levelized cost of electricity $(\mathrm{LCOE})^{45}$, which we compute as in ref. ${ }^{21}$. This reference uses cost-estimation formulae (see Extended Data Table 1 for details) developed by the Norwegian and US hydropower industries to estimate electricity production costs in early project phases ${ }^{46,47}$, and annualizes the investments using a discount rate of $10 \%$ over a 40 -year economic lifespan. The individual cost components include turbine, piping and power-station costs; costs for electro-technical equipment, power-line connection and site operation; and costs deriving from seismic hazard mitigation, land loss and possible population displacement. The components are mainly a function of: the installed turbine capacity, $P_{\mathrm{T}}$, which we impose to be large enough to accommodate the entire, theoretically possible production at each site; the design discharge, $Q_{\mathrm{D}}$ (see above); and geometrical parameters such as dam height, $D_{\mathrm{H}}$, dam length, $D_{\mathrm{L}}$, hydraulic head, $h$, and length of piping, $L_{\mathrm{p}}$, which are all given by our topographical analysis. Details on the calculations of the individual cost contributions are given in Extended Data Table 1, while Fig. 1c and Extended Data Fig. 6 provide overviews of the cost distribution. Following the price thresholds used in ref. ${ }^{21}$, we assign a score of 0 (or 100) for sites with production costs above $0.5 \mathrm{USD} \mathrm{kWh}^{-1}$ (or below $0.1 \mathrm{USD} \mathrm{kWh} \mathrm{Kh}^{-1}$ ), and we linearly interpolate the score in between. Note that the production costs are driven largely by the technical infrastructure, and that no distinction is made between price levels in different countries, because most components can be considered to be commodities.

\section{Data availability}

The data generated herein are available at http://doi.org/10.3929/ethz b-000353109. The reference list provides information on data obtained from third parties.

\section{Code availability}

The computer codes used for evaluations are available from the corresponding author upon request.

31. Jarvis, J., Guevara, E., Reuter, H. I. \& Nelson, A. D. Hole-filled SRTM for the globe: version 4: data grid http://srtm.csi.cgiar.org/ (CGIAR Consortium for Spatial Information, 2008)

32. Tachikawa, T., Hato, M. Kaku, M. \& Iwasaki, A. Characteristics of ASTER GDEM version 2. In Proc. IEEE Int. Geosci. Remote Sensing Symp. (IGARSS) 3657-3660 (IEEE, 2011).

33. Machguth, H. \& Huss, M. The length of the world's glaciers-a new approach for the global calculation of center lines. Cryosphere 8, 1741-1755 (2014).

34. Farinotti, D. et al. How accurate are estimates of glacier ice thickness? Results from ITMIX, the Ice Thickness Models Intercomparison eXperiment. Cryosphere 11, 949-970 (2017)

35. Jenson, S. \& Domingue, J. Extracting topographic structure from digital elevation data for geographic information-system analysis. Photogramm. Eng. Remote Sensing 54, 15931600 (1988)

36. Taylor, K. Stouffer, R. \& Meehl G. An overview of CMIP5 and the experiment design. Bull. Am. Meteorol. Soc. 93, 485-498 (2012)

37. Lloyd, C., Sorichetta, A. \& Tatem, A. High resolution global gridded data for use in population studies. Sci. Data 4, 170001 (2017)

38. de Ferranti, J. Digital Elevation Data http://www.viewfinderPanoramas.org/dem3.html (2014).

39. International Union for Conservation of Nature (IUCN) and UNEP-WCMC. KML layer of natural and mixed world heritage sites as recorded in the World Database on Protected Areas (WDPA). http://www.iucn.org/sites/dev/files/import/downloads/natural_and_mixed_ world heritage sites_2014.kmz (2013).

40. International Union for Conservation of Nature (IUCN) and UNEP-WCMC. The World Database on Protected Areas (WDPA). Protected Planet https://www.protectedplanet. net/ (2017).

41. International Union for Conservation of Nature (IUCN) and Center for International Earth Science Information Network. Gridded species distribution: global amphibian richness grids. https://sedac.ciesin.columbia.edu/data/set/species-global-amphibianrichness-2015 (NASA Socioeconomic Data and Applications Center (SEDAC), 2015).

42. International Union for Conservation of Nature (IUCN) and Center for International Earth Science Information Network. Gridded species distribution: global mammal richness grids. http://sedac.ciesin.columbia.edu/data/set/species-global-mammal-richness2015(NASA Socioeconomic Data and Applications Center (SEDAC), 2015).

43. Fischer, L., Purves, R., Huggel, C., Noetzli, J. \& Haeberli, W. On the influence of topographic, geological and cryospheric factors on rock avalanches and rockfalls in high-mountain areas. Natural Hazards Earth Syst. Sci. 12, 241-254 (2012).

44. Sevestre, H. \& Benn, D. Climatic and geometric controls on the global distribution of surge-type glaciers: implications for a unifying model of surging. J. Glaciol. 61 646-662 (2015).

45. International Renewable Energy Agency. Renewable energy technologies: cost analysis series Vol. 1 Power Sector Issue 3/5 https://www.academia.edu/12663204/renewable energy_technologies_cost_analysis_series (IREA, 2012).

46. SWECO Norge AS. Cost base for hydropower plants (with a generating capacity of more than 10,000 kW). http://publikasjoner.nve.no/veileder/2012/veileder2012_03.pdf (Norwegian Water Resources and Energy Directorate, 2012).

47. Hall, D., Hunt, R., Reeves, K. \& Carroll, G. Parameters of US Hydropower Resources. Contract No. INEEL/EXT-03-00662. Technical Report (Idaho National Engineering and Environmental Laboratory, 2003)

48. SWECO Norge AS. Cost base for small-scale hydropower plants (with a generating capacity of up to $10,000 \mathrm{~kW}$ ). http://publikasjoner.nve.no/veileder/2012/veileder2012 02 pdf (Norwegian Water Resources and Energy Directorate, 2012).

49. Giardini, D., Grünthal, G., Shedlock, K. M. \& Zhang, P. The GSHAP global seismic hazard map. Ann. Geophys. 42, 1225-1230 (1999).

50. Harris, J. Bonneville, D., Kersting, R. A. Lawson, J. \& Morris, P. Cost Analyses and Benefit Studies for Earthquake-Resistant Construction in Memphis, Tennessee-Design Drawings. Report No. 14-917-26, https://www.nist.gov/publications/cost-analyses-and-benefitstudies-earthquake-resistant-construction-memphis-tennessee-0. (NIST, 2013

51. Food and Agriculture Organization of the United Nations. FAOSTAT Annual producer prices 2015. http://www.fao.org/prices/en/\#data/PP (2015).

Acknowledgements This study was supported by the Swiss National Science Foundation (SNSF), grant number PZENP2_154290. We thank all those who made freely available any data used here; D. Gernaat for distance-to-powerline information used in the economic analysis; and D. Felix for punctual advice regarding hydropower infrastructure design.

Author contributions D.F. and V.R. conceived the study; M.H. produced the glacier runof projections and provided the DEMs necessary for the analyses; D.F. conceived and mplemented the code for the dam-construction analysis; V.R. conceived the suitability score system with the help of D.F. and H.Z.; V.R. performed global-scale calculations, and designed most figures; H.Z. and L.C. implemented and performed the economic analyses with the help of D.F., and assisted in figure design and production. The manuscript was drafted by V.R. and D.F., with contributions from M.H., H.Z. and L.C.

Competing interests The authors declare no competing interests.

\section{Additional information}

Correspondence and requests for materials should be addressed to D.F.

Peer review information Nature thanks Joseph Shea and the other, anonymous, reviewer(s) for their contribution to the peer review of this work.

Reprints and permissions information is available at http://www.nature.com/reprints. 


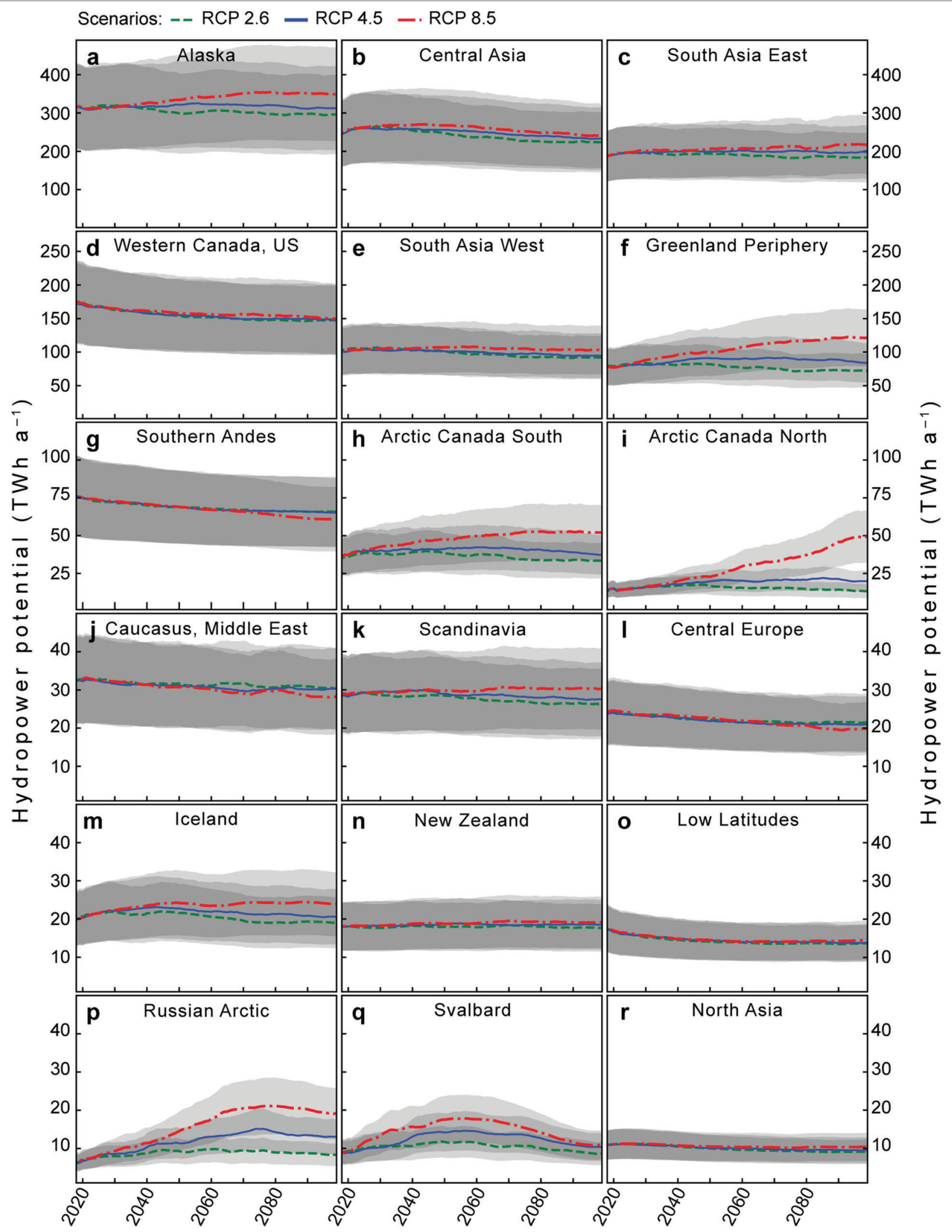

Extended Data Fig. 2 |Temporal evolution of the total hydropower potential from all considered basins within individual regions. Regional definitions for panels $\mathbf{a}-\mathbf{r}$ are in Extended Data Fig. 7 and follow the Randolph Glacier

based on selected representative concentration pathways ${ }^{23}$. Temporal variations reflect variations in runoff. Note that different vertical scales are used for each row. Grey shading indicates $95 \%$ confidence intervals. 

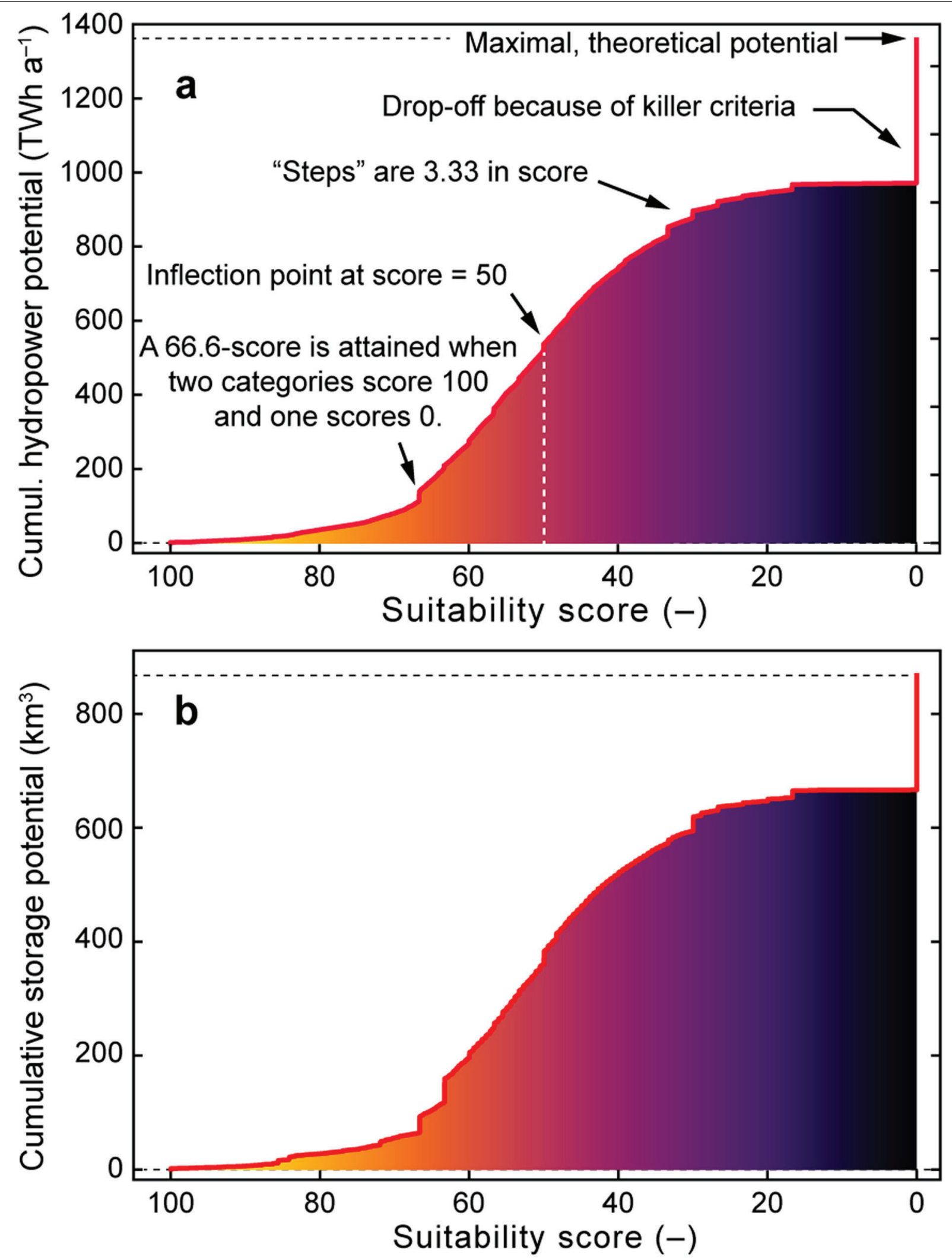

Extended Data Fig. 3 | Cumulative hydropower potential and potential reservoir volume for a given suitability score. a, b, Hydropower potential (a) and reservoir volume (b). The 'steps' in the suitability score are caused by some of the suitability indicators only taking discrete values, and the final suitability score being an average of three categories (see Methods). The inflection point at score 50 is marked, as are other features worth noticing. The suitability score is dimensionless. 


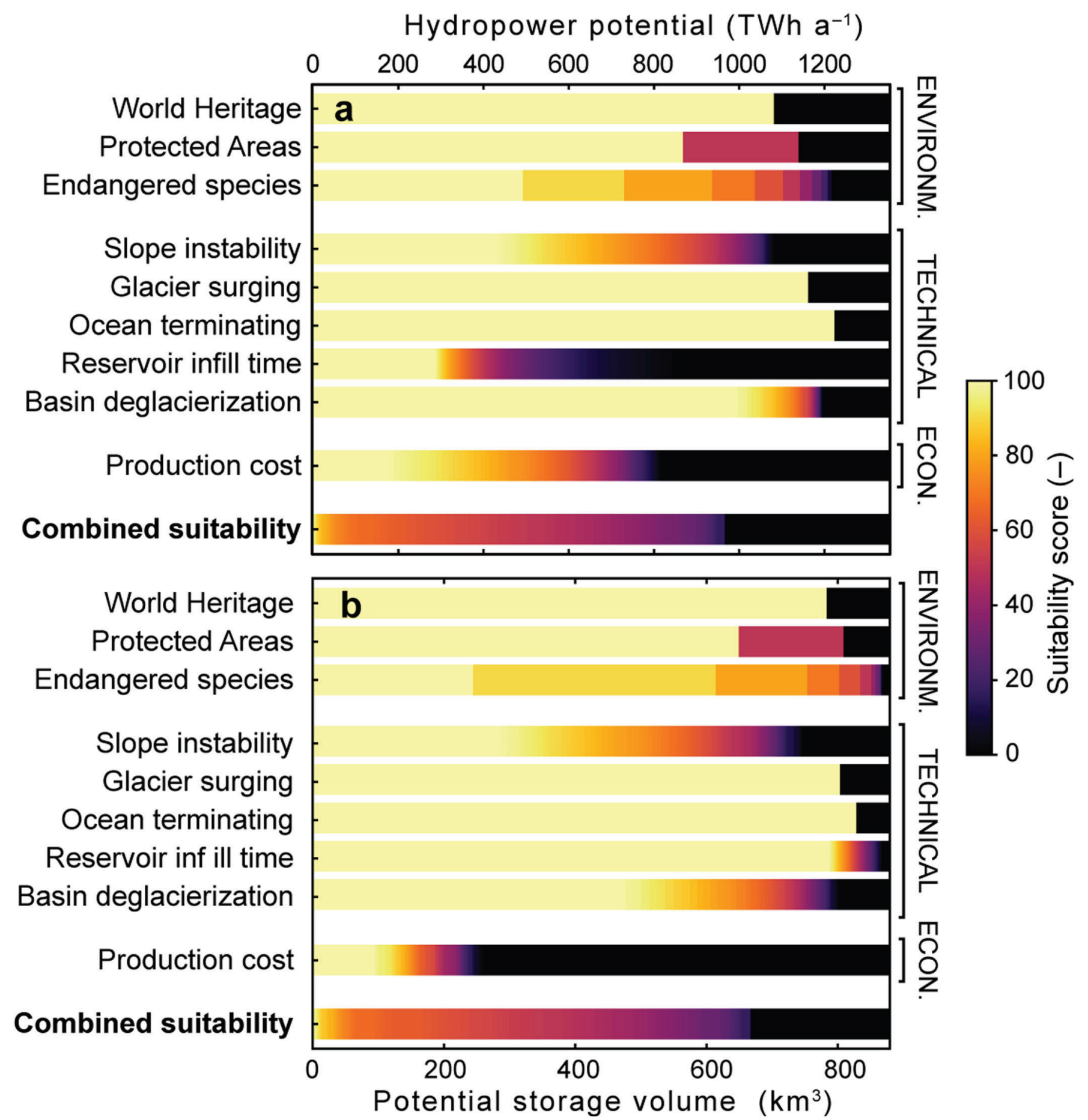

Extended Data Fig. 4 | Globally aggregated hydropower potential and potential storage volume as a function of suitability. a, b, Hydropower (environmental, technical or economic) is given individually. The last row of each panel shows the final suitability score (see Methods). 

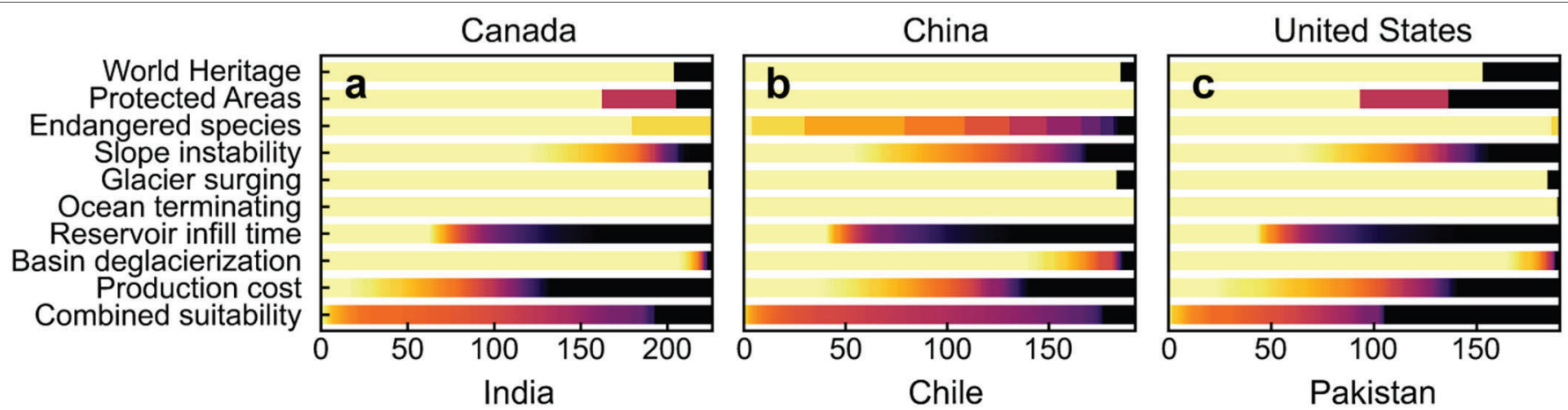

World Heritage

Endangered species

Slope instability

Glacier surging

Ocean terminating

Reservoir infill time

Basin deglacierization

Production cost

Combined suitability
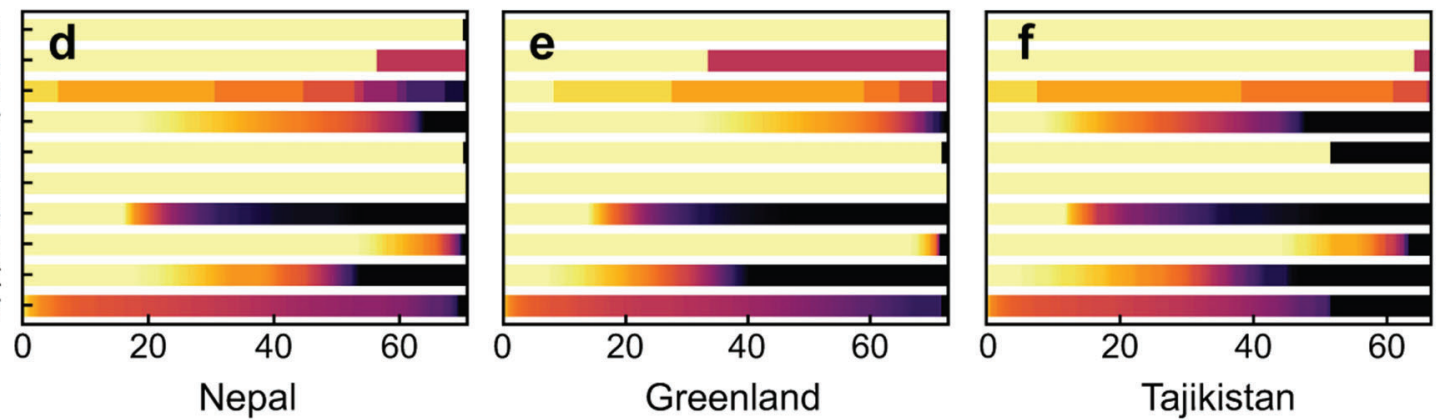

World Heritage

Protected Areas

Endangered species

Slope instability

Glacier surging

Ocean terminating

Reservoir infill time

Basin deglacierization

Production cost

Combined suitability
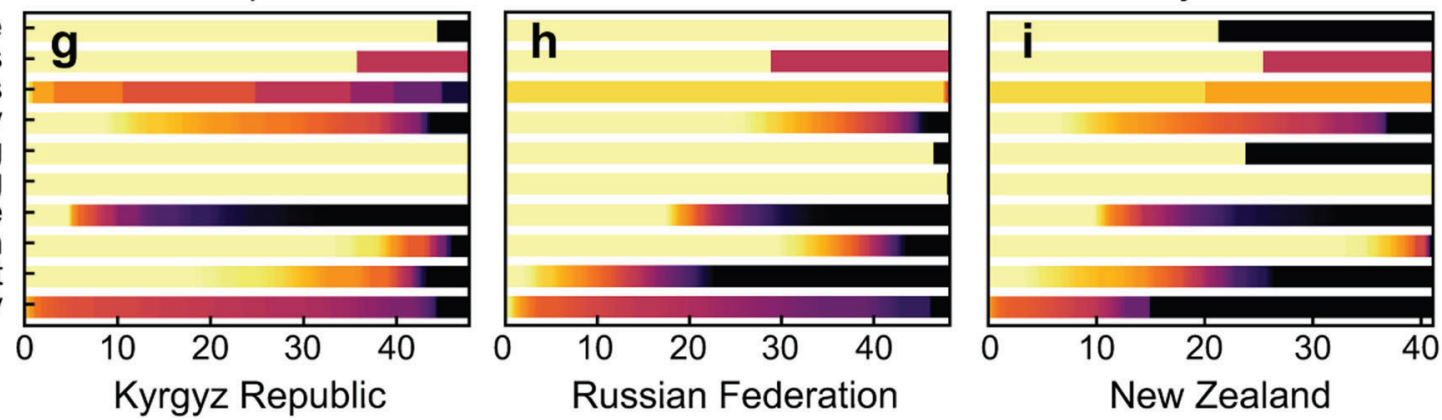

World Heritage

Protected Areas

Endangered species Slope instability

Glacier surging

Ocean terminating

Reservoir infill time

Basin deglacierization

Production cost

Combined suitability

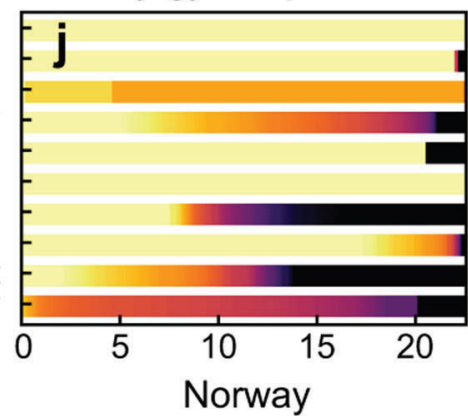

Russian Federation
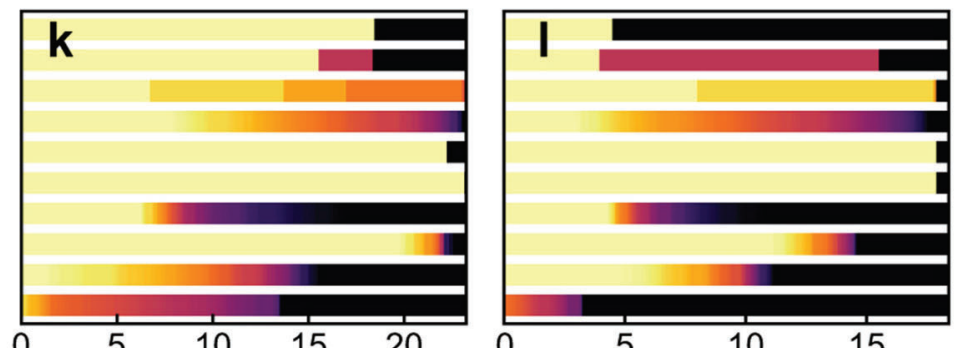

World Heritage

Protected Areas

Endangered species

Slope instability

Glacier surging

Ocean terminating

Reservoir infill time

Basin deglacierization

Production cost

Combined suitability
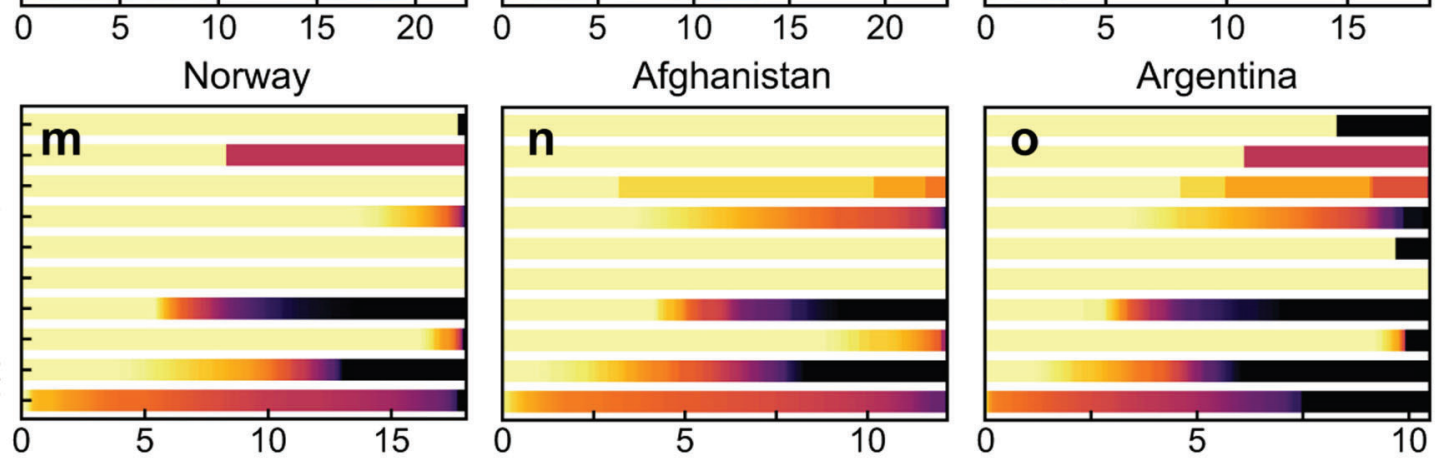

Extended Data Fig. 5 | Hydropower potential as a function of suitability, aggregated per country. a-o, The 15 countries with the highest cumulative hydropower potentials. Scores for individual indicators are given separately. 

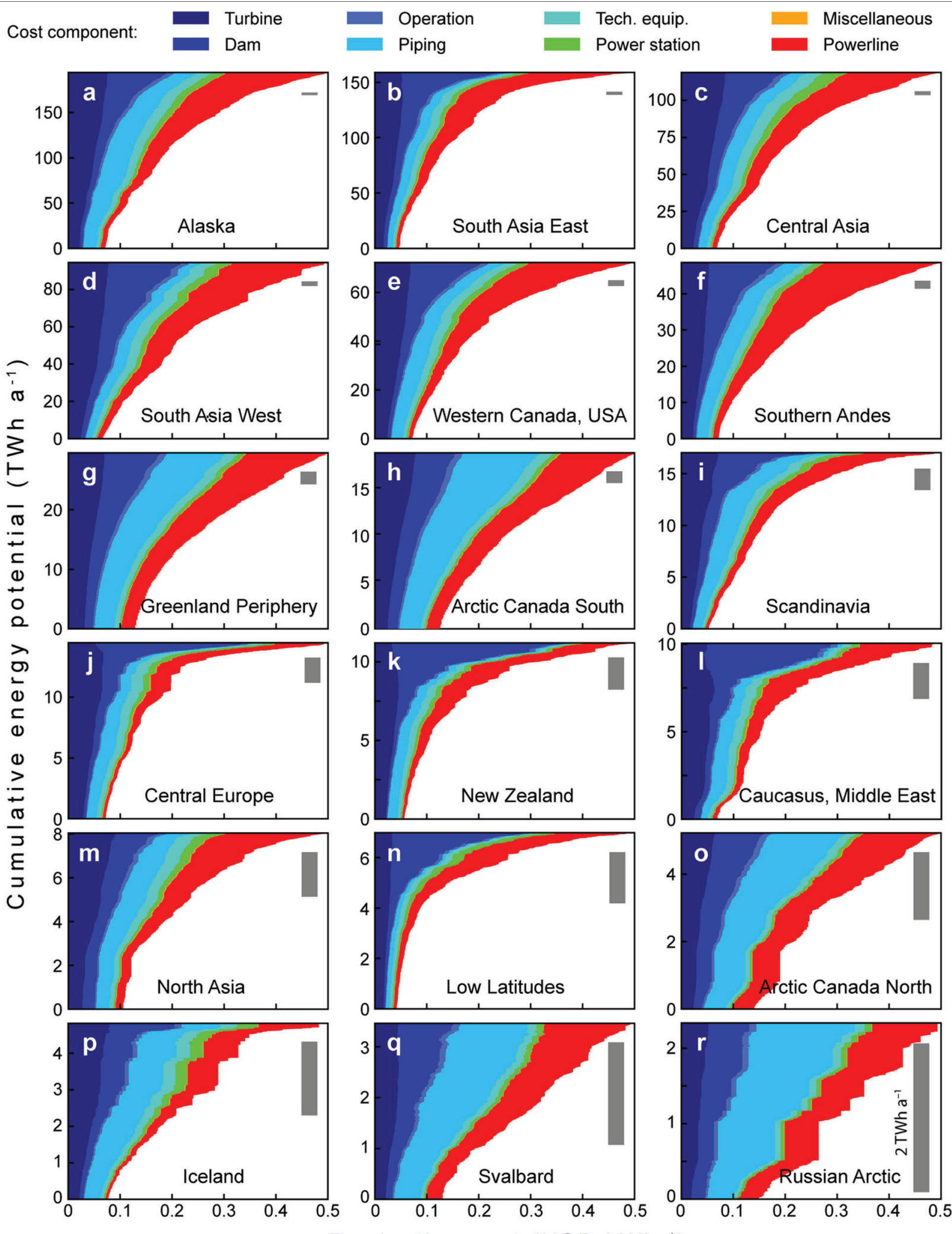

\section{Production cost (USD kWh-1)}

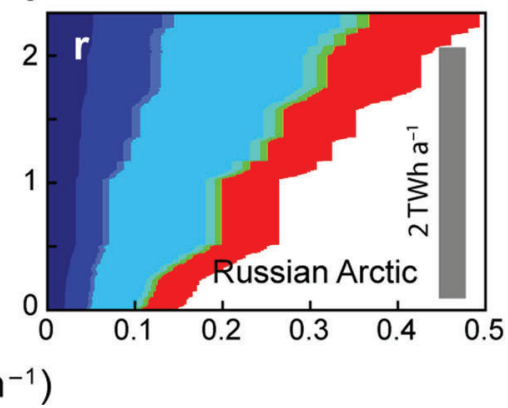

Extended Data Fig. 6 | Cumulative hydropower energy potential as a function of production cost in different regions of the world. a-r, Regions are defined in Extended Data Fig. 7, and are sorted according to the maximal potential for which the estimated production cost is below $0.5 \mathrm{USD} \mathrm{kWh}^{-1}$.
Different colours depict individual cost components (see Methods and Extended Data Table 1 for calculations). Note that the panels have different scales (the grey bars in the upper right corners are always equivalent to $3 \mathrm{TWh} \mathrm{yr}^{-1}$ ). 


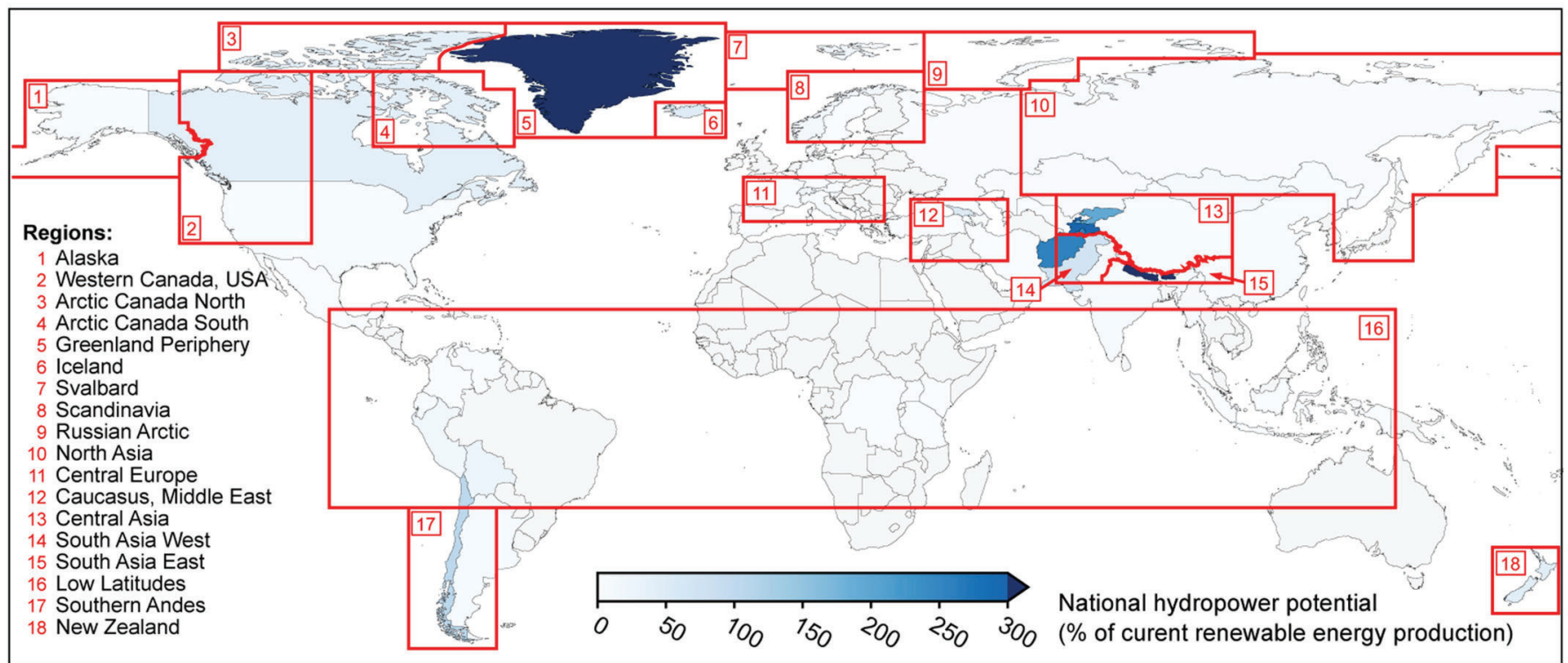

Extended Data Fig. 7 | Global distribution of the hydropower potential from deglacierizing basins, compared with present renewable electricity

production. The total maximal potential per country (blue shading) is shown as a percentage of the present renewable electricity production. Data for the latter are taken from the International Renewable Energy Agency ${ }^{16}$ for the year 2017. The red boxes indicate regions as defined in the Randolph Glacier Inventor $\mathrm{y}^{20}$ and are used for aggregating data in Extended Data Figs. 2, 6. The basemap was generated using Matplotlib ${ }^{30}$. 


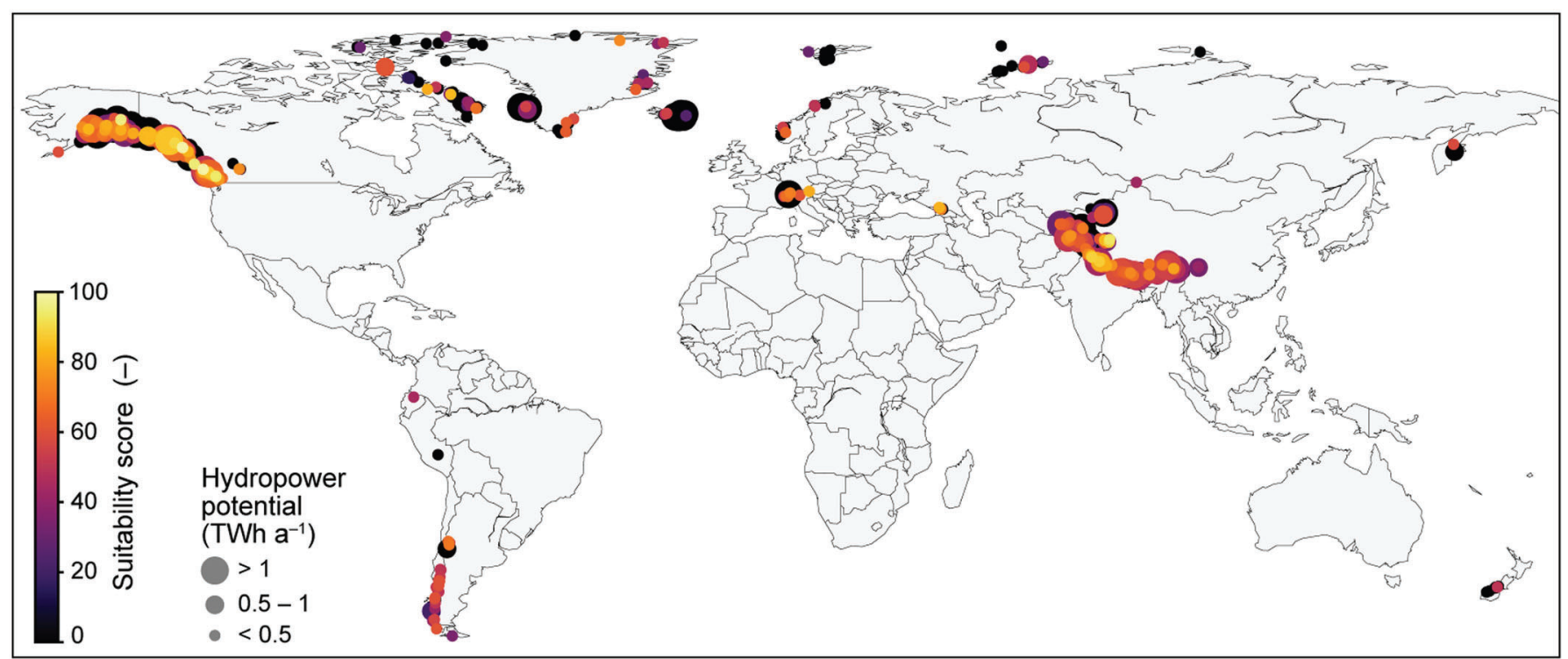

Extended Data Fig. 8 | Global distribution of the top 1,000 sites in terms of hydropower potential. Circle sizes and colours depict the hydropower potential and the suitability score, respectively. The basemap was generated using Matplotlib ${ }^{30}$.

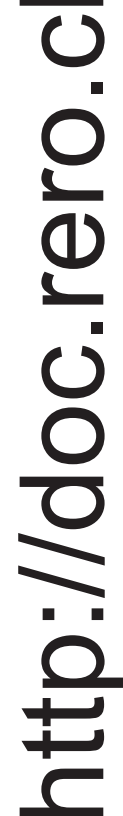



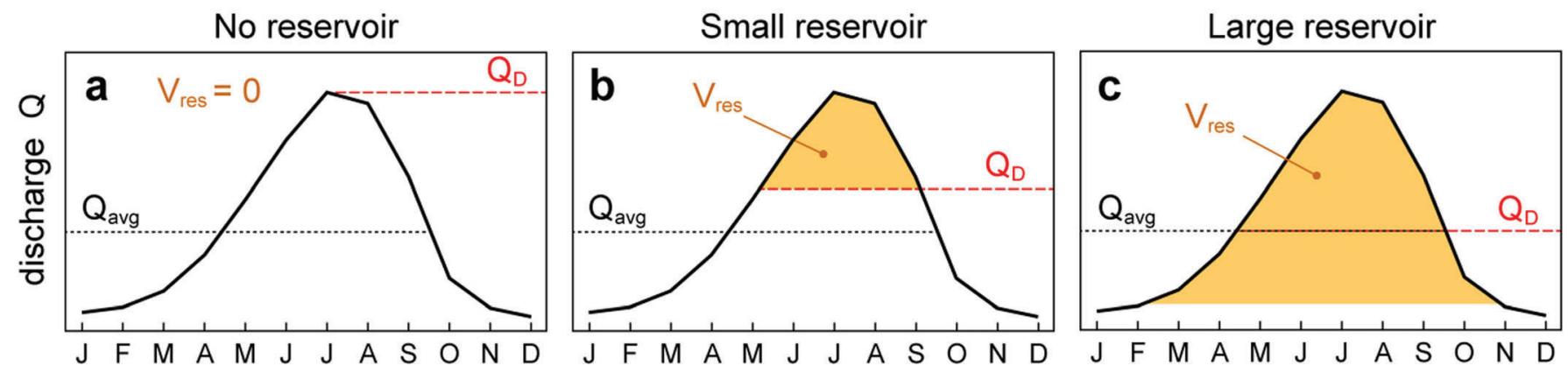

Extended Data Fig. 9 |Conceptual representation of the procedure used for the annual discharge every year requires $Q_{\mathrm{D}}$ to equal $Q_{\text {avg }}$ (a smaller $Q_{\mathrm{D}}$ would determining the design discharge $\boldsymbol{Q}_{\mathrm{D}} \cdot Q_{\mathrm{avg}}$ is the average monthly discharge imply water accumulation from year to year, thus leading to reservoir overspill $V_{\text {res }}$ (orange area) is the volume of the reservoir. Small and large reservoirs and production loss over time). Smaller reservoirs require a larger $Q_{D}$, because are discerned on the basis of annual discharge: a reservoir is considered to be less water can temporarily be stored. Letters on the $x$-axis denote months. 


\section{Extended Data Table 1| Equations used to compute hydropower production costs}

\begin{tabular}{|c|c|c|c|}
\hline Cost component & Equation & Notes & Ref. \\
\hline Turbine (USD) & $\begin{array}{c}p_{1}=1.943 P_{T}^{0.7634} 10^{6} \\
\quad \text { with } \\
P_{T}=Q_{D} h \rho g \eta 10^{-6}\end{array}$ & $\begin{array}{c}P_{T}: \text { turbine capacity }(\mathrm{MW}) \\
Q_{D}: \text { design discharge }\left(\mathrm{m}^{3} \mathrm{~s}^{-1}\right) \\
h \rho g \eta \text { : as in Equation } 1 \text { of the Methods section }\end{array}$ & 45 \\
\hline Power station (NOK) & $\begin{array}{cl}p_{2}=\left(-0.0006 Q_{D}^{2}+0.67 Q_{D}-6.95\right) 10^{6} & \text { (fo } \\
p_{2}=\left(0.4948 Q_{D}+1.7\right) 10^{6} & \text { (fo }\end{array}$ & $\begin{array}{l}\left.50 \mathrm{~m}^{3} \mathrm{~s}^{-1}\right) \\
\left.50 \mathrm{~m}^{3} \mathrm{~s}^{-1}\right)\end{array}$ & 46,48 \\
\hline Electro-technical equip.(NOK) & $p_{3}=3.9142 P_{T}^{0.6622} 10^{6}$ & & 46 \\
\hline Dam (NOK) & $p_{4}=0.72 D_{H}^{1.8} D_{L} 10^{3}$ & $\begin{array}{l}\qquad \begin{array}{c}D_{H}: \text { dam height }(\mathrm{m}) \\
D_{L}: \text { dam length }(\mathrm{m})\end{array} \\
\text { Note the wrong exponent in ref. }{ }^{21} \text { Table S5 }\end{array}$ & 46 \\
\hline Piping - headrace tunnel (NOK) & $\begin{array}{c}p_{5}=219.99 A_{t}+13658\left(L_{p}-h\right) m_{t} n_{p} \\
\text { where: } \\
A_{t}=Q_{D} / v \\
m_{t}=0.0054\left(L_{p} 10^{-3}\right)^{2}-0.0039\left(L_{p} 10^{-3}\right)+0.9671 \\
\text { Note that the low value for } v \text { cause }\end{array}$ & $\begin{array}{c}A_{t}: \text { tunnel cross section }\left(\mathrm{m}^{2}\right) \\
L_{p}: \text { length of the pipes }(\mathrm{m}) \\
h: \text { hydraulic head }(\mathrm{m}) \\
m_{t}: \text { tunnel length multiplier }(-) \\
n_{p}=1: \text { number of pipes }(-) \\
v=3 \mathrm{~m} \mathrm{~s}^{-1}: \text { flow rate in the pipe }\left(\mathrm{m}^{3} \mathrm{~s}^{-1}\right) \\
A_{t} \text { and thus conservatively high cost estimates. }\end{array}$ & 46 \\
\hline Piping - penstock (NOK) & $p_{6}=\left(6 D_{t}+9.4 h\right) n_{p} 10^{3}$ & $D_{t}=2 \sqrt{A_{t} / \pi}:$ tunnel diameter $(\mathrm{m})$ & 46 \\
\hline Miscellaneous (NOK) & $p_{7}=\left(-38.795 \log Q_{D}+309.89\right) P_{T} 10^{3}$ & Note the missing parenthesis in ref. ${ }^{21}$ Table S5 & 46 \\
\hline Power line connection (NOK) & $p_{8}=L p_{p}$ & $\begin{array}{c}L: \text { distance to next power line using } \\
\text { OpenStreetMap data by ref. }{ }^{21}(\mathrm{~km}) \\
p_{p}: P_{T} \text {-dependent power-line price }\left(\mathrm{NOK} \mathrm{km} \mathrm{km}^{-1}\right)\end{array}$ & 46 \\
\hline Seismic hazard mitigation (USD) & $p_{9}=0.05 \sum_{i=1}^{8} p_{i}$ & $\begin{array}{l}\text { Only for sites with medium or high seismic risk } \\
\text { according to the Global Seismic Hazard Map }{ }^{49}\end{array}$ & 49,50 \\
\hline Owner cost (USD) & $p_{10}=0.20 \sum_{i=1}^{9} p_{i}$ & & 45 \\
\hline Operation and maintenance (USD) & $M_{t}=0.02 \sum_{i=1}^{10} p_{i}$ & & 45 \\
\hline Fish passage & Not required (no fish in glacierized areas) & Ref. ${ }^{21}$ computed a cost based on ref. ${ }^{51}$ & - \\
\hline Agricultural land loss & No cost (no agriculure in glacierized areas) & $\begin{array}{l}\text { Ref. }{ }^{21} \text { computed a cost based on the revenues } \\
\text { that agricultural production would generate if the } \\
\text { reservoir-area was cultivated. }\end{array}$ & - \\
\hline Population displacement & No cost (no populatio in glacierized areas) & $\begin{array}{l}\text { Ref }{ }^{21} \text { computed a cost based on the number of } \\
\text { people displaced because of inundation. }\end{array}$ & - \\
\hline Total cost (USD kWh-1) & $L C O E=\frac{\sum_{t=0}^{n}\left(\left(I_{t}+M_{t}\right)(1+r)^{-t}\right)}{\sum_{t=0}^{n}\left(E_{t}(1+r)^{-t}\right)}$ & $\begin{array}{c}I_{t}: \text { investment for year } t(\mathrm{USD}) \\
I_{0}=\sum_{i=1}^{10} p_{i} ; I_{t}=0 \text { for } t>0 \\
M_{t}: \text { operation and maintenance in year } t(\mathrm{USD}) \\
E_{t}: \text { energy production in year } t(\mathrm{kWh}) \\
r=0.1: \text { discount rate }(-) \\
n=40: \text { system design life time (years) }\end{array}$ & 45 \\
\hline
\end{tabular}

Hydropower production costs are taken as the levelized cost of electricity (LCOE). The calculations of individual cost components $p_{i}$ follow ref. ${ }^{21}$. Costs are in 2010 US Dollars (USD). 1 NOK is approximately 0.12 USD. Equations are from refs. ${ }^{45,48-51}$. 